\title{
Таказов Ф.М.
}

\section{Орнитоморфные помощники героя в фольклоре осетин в контексте инициации}

Северо-Осетинский института гуманитарных и соџиальных исследований им. В. И. Абаева - филиал ФГБУН Федеральный научный цеентр «Владикавказский научный центр Российской академии наук»

(Россия, Владикавказ)

doi: 10.18411/trnio-12-2021-281

\section{Аннотация}

В статье рассматривается распространенный у многих народов типологический сюжет, в котором герой спасает птенцов орла в нижнем мире, за что благодарная орлицамать доставляет его в верхний мир. Сюжетная линия сказки и эпического сказания в фольклоре осетин по формальным внешним признакам не совпадают, однако основная фабула сохраняет сходные черты с типологическим сюжетом мирового фольклора. Как показывает анализ рассмотренных нарративных текстов, в основе сюжета лежит обряд инициации. При этом помощниками героя (неофита) во время прохождения инициации выступают птенцы и орел.

Ключевые слова: инициации, неофит, сказка, миф, орел, орнитоморфные помощники, нижний мир, подземелье.

\section{Abstract}

The article examines a typological plot common among many peoples, in which the hero saves the eagle chicks in the lower world, for which the grateful mother eagle delivers him to the upper world. The storyline of a fairy tale and an epic tale in Ossetian folklore do not coincide in formal external features, but the main plot retains similar features with the typological plot of world folklore. As the analysis of the considered narrative texts shows, the plot is based on the rite of initiation. At the same time, the helpers of the hero (neophyte) during the initiation are chicks and an eagle.

Keywords: initiations, neophyte, fairy tale, myth, eagle, ornithomorphic assistants, lower world, dungeon.

Значительное место в фольклоре и мифологии осетин занимает образ птиц. В мифофольклорной традиции осетин птицы выполняют различные функции. Так, например, орел маркирует Ось мира, выступая зооморфным образом Бога, ворона/ворон выполняет функции культурного героя, проявляет качества шамана, а ласточка исполняет роль посредника между Богом и людьми [11, с. 164]. Иногда птицы, вернее птенцы, выступают в качестве помощников героя.

В одном из сюжетов осетинских эпических сказаний о нартах герою помогают вернуться домой птенцы орла. Нарт Сослан во время охоты заблудился и, спускаясь вниз по глубокому оврагу, поросшему кустарником, попал в царство мертвых. После долгих скитаний в царстве мертвых, во время которых повидал много дивного, женился на дочери повелителя царства мертвых Барастура. Однако вскоре Сослан стал скучать по своему дому и решил вернуться. Во время долгого пути по пустынной равнине он увидел огромное дерево. Обрадовавшись, что появилась возможность отдохнуть в тени, Сослан полез на дерево. На дереве он обнаружил гнездо с орлиными птенцами. Птенцы обрадовались Сослану, назвав его по имени. В это же время в сторону гнезда ползла огромная змея с целью съесть птенцов. Сослан, недолго думая, убил ту змею. Птенцы спрятали Сослана, чтоб его не убил вернувшийся орел. Рассказав матери о герое, спасшем их от змеи, птенцы представили Сослана орлу. Орел, за то, что Сослан спас его птенцов, согласился доставить его на землю из седьмого подземелья. Каждый раз, когда орел преодолевал один уровень подземного 
царства, Сослан бросал в его клюв тушу буйвола и бурдюк вина («Сказание о том, как Нарт Сослан вернулся из Царства мертвых») [3, с. 541-549].

Мотив спасения героем птенцов и помощь благодарной матери в возвращении героя домой встречается и в сказках осетин.

В сказке «О семиголовом уаиге и залиаг-змее» у старика и старухи было три сына. Все три сына по очереди отправляются за хребет, чтоб убить уаига (великана) и залиаг-змею. По дороге им приходится пройти различные испытания. Менее проворные старшие сыновья были съедены уаигом. Младший сын, оказавшийся смышленей своих братьев, одолевает уаига и возвращает к жизни братьев. Старшие братья хитростью заманили младшего брата в яму и засыпали землей. В итоге младший брат очутился в подземном мире. Он убивает залиаг-змею, преградившей путь к воде жителям подземного мира. В благодарность за свое спасение жители подземного мира послали за большим орлом и посадили на его широкие крылья юношу. По мере того, как орел поднимался все выше и выше, юноша бросал в его клюв огромные куски мяса [5, с. 18-23].

Мотив возвращения героя из подземного/нижнего мира благодарным орлом за спасение птенцов широко распространен по всему миру. Сюжет, в котором герой спасает от змея, а благодарная птица-мать выносит его в нужное ему место, встречается у народов Индии, Ближнего Востока, Азии, Европы, Кавказа и Африки. Отличаясь в деталях, все национальные версии отражают единый типологический сюжет: герой оказывается в подземном мире, он спасает птенцов, благодарная птица-мать доставляет героя в нужное ему место.

Наиболее близок к осетинскому сюжету грузинская сказка «Три брата». В грузинской сказке старшие братья также, как и в осетинской, предают более успешного младшего брата, в результате чего он оказывается в нижнем мире. Он освобождает жителям подземной страны путь к воде, который преградил гвелешапи. Юноша поднимается в гору, где живет орел. Птенцы прячут его, затем рассказывают о его поступке орлу, который в знак благодарности доставляет на землю. По мере того, как он поднимается выше, юноша бросает ему в клюв куски мяса. Когда мясо закончилось, юноша отрезал кусок от своей ноги. Однако, как и в осетинской сказке, орел не проглатывает последний кусок, а после того, как поднялись в верхнюю страну, приклеивает кусок ноги на место [2, с. 79-83]. В дагестанской сказке «Богатырь» герой спасает птенцов орла не от змея, а от коршуна. В остальном сценарий сходен с осетинским и грузинским [9, с. 280-290]. Богатырь Найхал в калмыцком фольклоре во время прохождения испытаний попадает в нижний мир. Он убивает змею и спасает птенцов. Благодарная мать-орлица выносит его в верхний мир. Во время полета богатырь кормит орлицу кониной и кумысом [7, с. 81-94]. Сходный сюжет бытует и у кабардинцев [8, с. 111-119], абхазов [1, с. 353-361], карачаевцев и балкарцев [4, с. 383-387].

Сходные сюжеты бытуют и за пределами Кавказа. Хотя сюжетная линия у всех народов выстраивается с учетом особенностей национальных фольклорных традиций, однако всем вариантам характерно сходство фабулы: завязка - два/три брата отправляются убить великана/злодея, младший не только побеждает великана/злодея, но и вызволяет старшего брата/братьев; интрига - спасенный старший брат/братья предает младшего брата, в результате чего тот оказывается в нижнем мире/глубокой яме/подземелье/глубоком колодце; кульминация - в нижнем мире/подземелье младший брат проходит различные испытания, совершает героические поступки; развязка - герой спасает птенцов орла от змея, по возвращении матери-орлицы птенцы прячут юношу, рассказывают матери о его поступке, орлица, в благодарность за спасение птенцов, выносит юношу в верхний мир или место, которое указывает герой, во время полета юноша кормит орла мясом буйвола/коня и вином/кумысом/водой, однако мяса не хватает и юноша отрезает от своей ноги кусок, орлица прячет за языком этот кусок и после приземления она прилепляет к ноге юноши отрезанный кусок; эпилог - младший брат возвращается домой, коварный брат/братья получает по заслугам. 
В основе рассмотренного сюжета, безусловно, лежит обряд инициации. Еще В.Я. Пропп доказал, с привлечением обширного материала, что в основе сказки и мифа лежит обряд инициации [6, с. 9].

В рассматриваемом сюжете просматриваются все признаки посвящения героя. Во время инициации неофит (герой) покидает дом и отправляется в дальний путь для достижения определенных целей: охота [3, с. 541], убийство живущего за хребтом великана (уаига) [Осетин. Сказки, с. 18].

Неофит (герой) на всем пути прохождения инициации подвергается различным испытаниям, которые он проходит достойно. При этом он не обходится без помощников. Присутствие помощника в сказке или мифе - показатель инициационного характера нарративного текста. И в рассматриваемой осетинской сказке и эпическом произведении, как, впрочем, и в национальных типологических сюжетах других народов, таким помощником выступают птенцы и орел.

На архаичность данного сюжета указывает тот факт, что в нем сохранилась символика трехчастной структуры мироздания, даже у народов, у которых в религиозномифологических воззрениях такое деление мира перестало быть значимой. Так, во всех национальных вариантах неофит (герой) попадает в нижний мир/подземелье/глубокую яму, что становится кульминацией сюжетной линии. При прохождении инициации неофит только тогда переходит в новый статус, когда он успешно преодолевает испытания в нижнем мире и благополучно возвращается в свой мир. При этом в средний/верхний мир его непременно должен доставить орел, способный проникать во все три мира [10, с. 182-193.].

Орел, после того как доставляет героя домой/верхний мир, исцеляет ногу юноши, возвратив ему отрезанный от ноги кусок мяса, что знаменует успешное прохождение неофитом испытание нижним миром, так как нижний мир - показатель символической смерти героя, одного из главных показателей инициационного характера текста.

Наличие у неофита старших братьев, также указывает на инициационный характер сюжета. Герой, после возвращения домой, может перейти в новый статус лишь после того, как он заменит старшего брата. Только после смерти брата/братьев завершается инициационный путь неофита.

$$
* * *
$$

1. Грузинские народные сказки /Составитель Т.Д. Курдованидзе. М.: Наука, 1988. - 363 с.

2. Нартовские сказания. Эпос осетинского народа / Сост. Т. А. Хамицаева. Кн. 2. - Владикавказ: ИПЦ СОИГСИ, 2004. - 896 с. (На осетинском яз.).

3. Нарты. Героический эпос балкарцев и карачаевцев /Составит. А.И. Алиева. М.: Наука, 1994. - 656 с.

4. Осетинские народные сказки /Составитель Бязыров А.Х. Цхинвал: Ирыстон, 1978. - 270 с.

5. Пропп В.Я. Исторические корни волшебной сказки. 2-е изд. Л.: Изд-во ЛГУ, 1986. - 364 с.

6. Сандаловый ларец. Калмыцкие народные сказки / Составление и перевод Т.Г. Басанговой. Элиста: Калмыцкое книжное издательство. - 239 с.

7. Сказки адыгских народов /Составитель А.И. Алиева. М.: Наука, 1978. - 406 с.

8. Сказки народов Северного Кавказа. Ростов-на-Дону: Ростовское книжное издательство, 1959. - 295 с.

9. Таказов Ф.М. Архетип орла в фольклоре осетин // Скифо-аланское наследие Кавказа. Сборник научных трудов. Владикавказ: ИПО СОИГСИ, 2017. - С. 182-193.

10. Таказов Ф.М. Образ птиц в мифологии и фольклоре осетин // Вопросы литературы и фольклора. Вып. Х. Ч. 1. Владикавказ: СОИГСИ ВНЦ РАН, 2018. - С. 139-163.

Тарасова К.Р., Ордахова Т.В. Анализ образа Сяо Фуцзы в произведении Лао Шэ «Рикша»

Северо-Восточный федеральный университет (Россия, Якутск)

doi: 10.18411/trnio-12-2021-282

Аннотация

В данном исследовании мы выявили особенности перевода описания образов женщины в китайской культуре. Мы раскрыли особенности и трудности, с которыми 